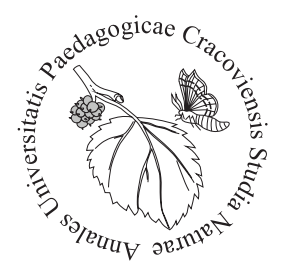

Katarzyna Możdżeń*, Patrycja Zagata Leśnicka, Mateusz Ślęczka, Magdalena Greczek-Stachura Institute of Biology, Pedagogical University of Kraków, Podchorążych 2 St., 30-084 Kraków, Poland, "katarzyna.mozdzen@up.krakow.pl

\title{
The photosynthetic activity of Paramecium bursaria endosymbiotic algae in varying temperature conditions
}

Introduction

Microbial organisms are ideal to study adaptation to a variable environment. They are characterised by large population sizes, short generation time, and the ability to manipulate their environment in controlled conditions (Jessup et al., 2004).

Paramecium bursaria Ehrenberg 1831 is cosmopolitan organism, inhabiting standing or slowly flowing water with relatively high purity. P. bursaria forms the endosymbiotic relationship with algae of Chlorella species (Reisser, 1980). This relationship is an unusual example of optional and mutualist interaction between the two species. There are up to several hundred symbiotic algae inside the cell of $P$. bursaria (Karakashian et al., 1968) (Fig. 1). The symbiotic algae are enclosed in a perialgal vacuole membrane (derived from the host digestive vacuole), and this membrane protects the algae from the hosts lysosomal digestion (Kodama, Fujishima, 2005). The host cell protects endosymbionts from infections by Chlorella virus. Paramecium supply algal cells with nitrogen components and the $\mathrm{CO}_{2}$ necessary for photosynthesis (Reisser, 1980; Albers, Wiessner, 1985; Kodama, Fujishima, 2005). Green endosymbionts carry out photosynthesis and thus provide the host with maltose and oxygen (Brown, Nielsen, 1974); therefore, $P$. bursaria becomes completely or partially independent of the external source of food (Sommaruga, Sonntag, 2009).

Endosymbionts inside P. bursaria are sensitive to different environmental factors, e.g., temperature. Long-term exposure ciliates to low temperatures may cause changes in the early stages of development of their metabolism and consequently lead to the microorganisms extinction (unpublished). Global warming leads to changes in the process of photosynthesis and respiration in autotrophic organisms. PSII seems to be one of the most thermo-sensitive protein complex pigments, which regulates photosynthetic activity in algae, cyanobacteria, as well as in higher plants (Strasser et al., 

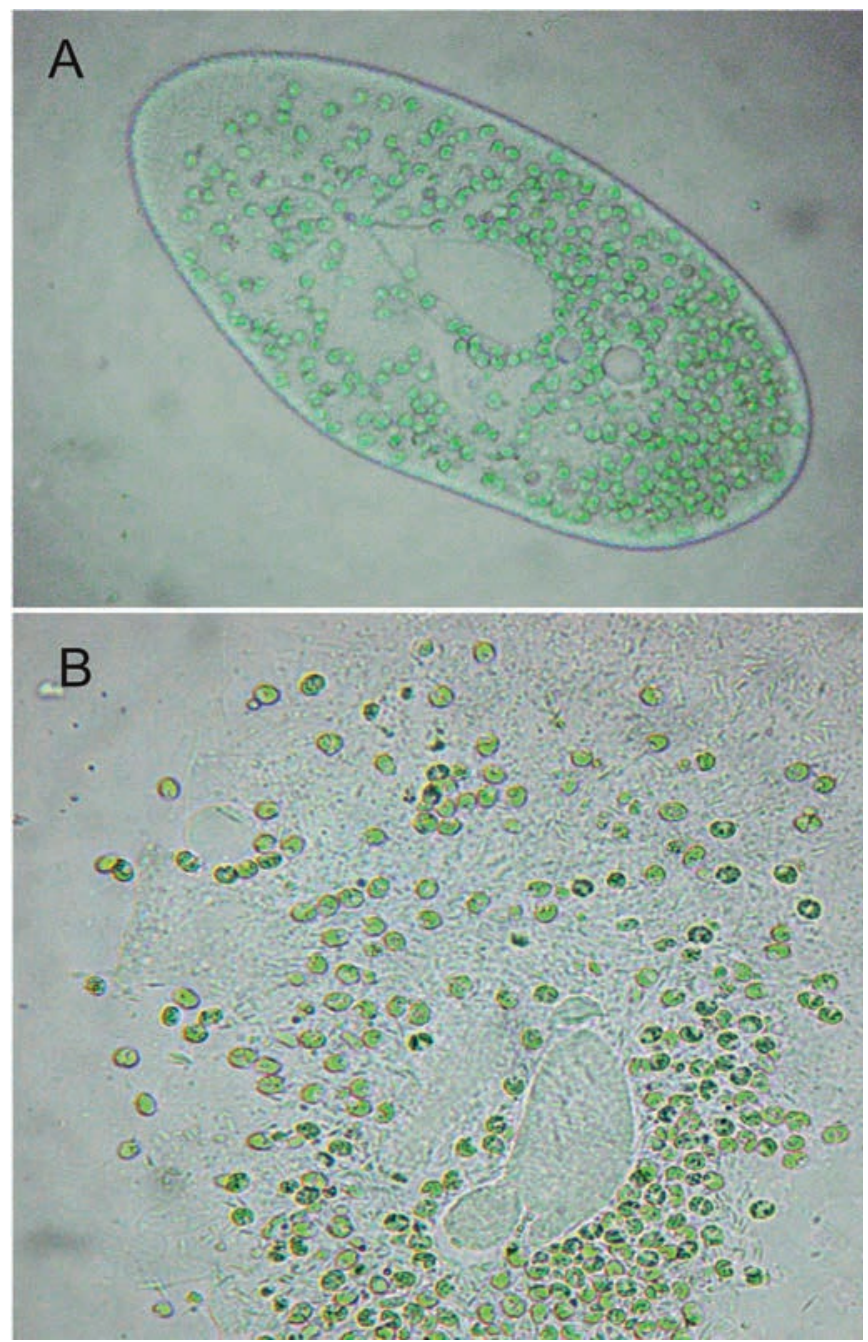

Fig. 1. Paramecium bursaria with green endosymbionts - A; endosymbiotic algae isolated from the Paramecium bursaria cell - B (Photo. M. Ślęczka)

1995; Morgan-Kiss et al., 2006). Chlorella vulgaris Beijer. cells regulate photosynthetic processes at the level of LHCII polypeptides, chlorophyll molecules, as well as through the xanthophyll cycle, in response to different temperatures and light intensities (Wilson, Huner, 2000).

The aim of this study was to investigate the effects of temperatures $\left(21^{\circ} \mathrm{C}, 24^{\circ} \mathrm{C}\right.$, $27^{\circ} \mathrm{C}, 30^{\circ} \mathrm{C}$, and $33^{\circ} \mathrm{C}$ ) on the photosynthesis carried out by endosymbiotic green algae of two P. bursaria strains from warm climate (Ardmore, USA) with an average annual temperature of $+23.7^{\circ} \mathrm{C}$ (Ard7) and from cold climate (Kamchatka, Russia) with an average air temperature of $-6^{\circ} \mathrm{C}(\mathrm{KD} 64)$. 
The experiments were conducted at the Institute of Biology of Pedagogical University of Kraków. The study material was Paramecium bursaria strains from (1) Kamchatka (KD64) located in the Asian part of Russia $\left(58^{\circ} 36^{\prime} 40^{\prime \prime} \mathrm{N}\right.$; $\left.38^{\circ} 54^{\prime} 44^{\prime \prime} \mathrm{E}\right)$ and (2) Ardmore (Ard7) located in the south-eastern Carter County, Oklahoma, United States $\left(34^{\circ} 10^{\prime} 52^{\prime \prime} \mathrm{N} ; 97^{\circ} 07^{\prime} 46^{\prime \prime} \mathrm{W}\right)$.

\section{Paramecium bursaria culture techniques}

Green Paramecium bursaria strains were grown on a lettuce medium with Klebsiella pneumoniae (SMC strain) (Sonneborn, 1970). The cultures were maintained under constant light/dark cycle (12L:12D) at $18^{\circ} \mathrm{C}$, at light intensity $200 \mu \mathrm{mol} \mathrm{m}^{-2} \mathrm{~s}^{-1}$ for 7 days at the following temperatures: $21^{\circ} \mathrm{C}, 24^{\circ} \mathrm{C}, 27^{\circ} \mathrm{C}, 30^{\circ} \mathrm{C}$ and $33^{\circ} \mathrm{C}$.

\section{Chlorophyll $a$ fluorescence}

Chlorophyll $a$ fluorescence was measured using a Handy Plant Efficiency Analyser fluorimeter (Hansatech Instruments, United Kingdom). A $1 \mathrm{ml}$ sample, with green P. bursaria, was taken into glass cell, then the sample was darkened for 5 minutes
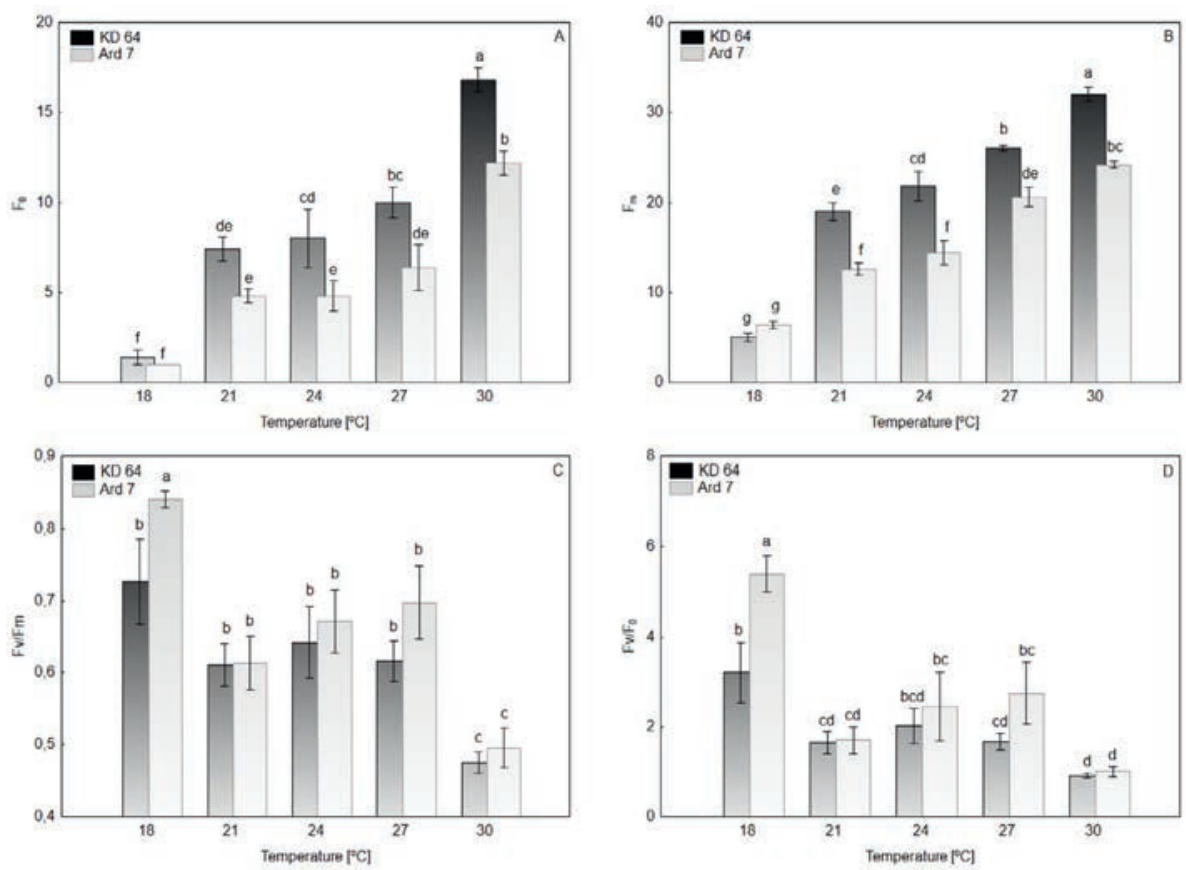

Fig. 2. Chlorophyll $a$ fluorescence parameters of Paramecium bursaria strains: KD64 and Ard7, incubated at different temperatures; different letters differ significantly according to the Duncan test at $\mathrm{p} \leq 0.05 ; \mathrm{n}=5$ 
to make the conditions needed to expire the light phase of photosynthesis. The obtained results were analysed as follows: $\mathrm{F}_{0}$ - chlorophyll fluorescence intensity measured when all photosystem II reaction centres are open, $\mathrm{F}_{\mathrm{m}}$ - maximal chlorophyll fluorescence intensity measured when all photosystem II reaction centres are closed, $\mathrm{F}_{\mathrm{v}}$ - variable chlorophyll fluorescence $\left(\mathrm{F}_{\mathrm{m}} / \mathrm{F}_{0}\right), \mathrm{F}_{\mathrm{v}} / \mathrm{F}_{0}$ - efficiency of the water-splitting complex on the donor side of PSII and $\mathrm{F}_{v} / \mathrm{F}_{\mathrm{m}}$ - maximum quantum yield of PSII. In addition, $\mathrm{T}_{\mathrm{fm}}$ - time needed for reaching $\mathrm{F}_{\mathrm{m}}(\mathrm{ms}), \mathrm{RC} / \mathrm{ABS}$ - index expression as the density of reaction centres (RC), PI - indicator of the functioning of PSII, TRo/RC trapped energy flux per cross section $(\mathrm{RC})$ at $t=0, \mathrm{ETo} / \mathrm{RC}$ - electron transport flux per cross section (RC) at $\mathrm{t}=0$, and $\mathrm{Vj}$ - relative change in chlorophyll fluorescence during the light phase of photosynthesis.

\section{Emission fluorescence - spectrofluorimetry method}

Measurement of blue-green and red fluorescence emission spectra were performed according to Lichtenthaler et al. (2004) with a spectrofluorimeter (Perkin-Elmer LS55B, United Kingdom) equipped with a liquid measuring device. Measurements of fluorescence intensity in the range of blue-green light $(430-650 \mathrm{~nm})$ were performed at $390 \mathrm{~nm}$ and near and far red $(650-800 \mathrm{~nm})$ with blue $430 \mathrm{~nm}$. The slot for the excitation radius was $15 \mathrm{~nm}$, and for the emitted $20 \mathrm{~nm}$. Results were analysed using FL WinLab version No. 3.00 .

\section{Statistic analysis}

A parametric multi-factorial ANOVA / MANOVA test was used to compare the variables tested, based on multiple Duncan homogeneous tests at $p \leq 0.05 ; n=5$. Calculations were made using StatSoft, Inc. (2014). STATISTICA¹2. Program.

Results

The minimum $\left(\mathrm{F}_{0}\right)$ and maximum $\left(\mathrm{F}_{\mathrm{m}}\right)$ fluorescence values for both strains increased with temperature. The highest $\mathrm{F}_{0}$ values were observed at $30^{\circ} \mathrm{C}$. Parameters of maximum PSII $\left(\mathrm{F}_{\mathrm{v}} / \mathrm{F}_{\mathrm{m}}\right)$ photochemical efficiency and maximum splash water yield after PSII donor side $\left(\mathrm{F}_{\mathrm{v}} / \mathrm{F}_{0}\right)$ were highest at $18^{\circ} \mathrm{C}$ and lowest at $30^{\circ} \mathrm{C}$ for two Paramecium bursaria strains (Fig. 2).

The chlorophyll $a$ fluorescence values were considerably different at tested temperatures compared to the control group. The chlorophyll fluorescence parameters $\left(\mathrm{F}_{0}\right.$ and $\left.\mathrm{F}_{\mathrm{m}}\right)$ were significantly higher for the KD64 strain compared to the Ard7 strain (Fig. 2-3).

The blue-green and red fluorescence emission spectra in KD64 and Ard7 strains were similar in the shape (Fig. 4). The increase of blue-green emission fluorescence 

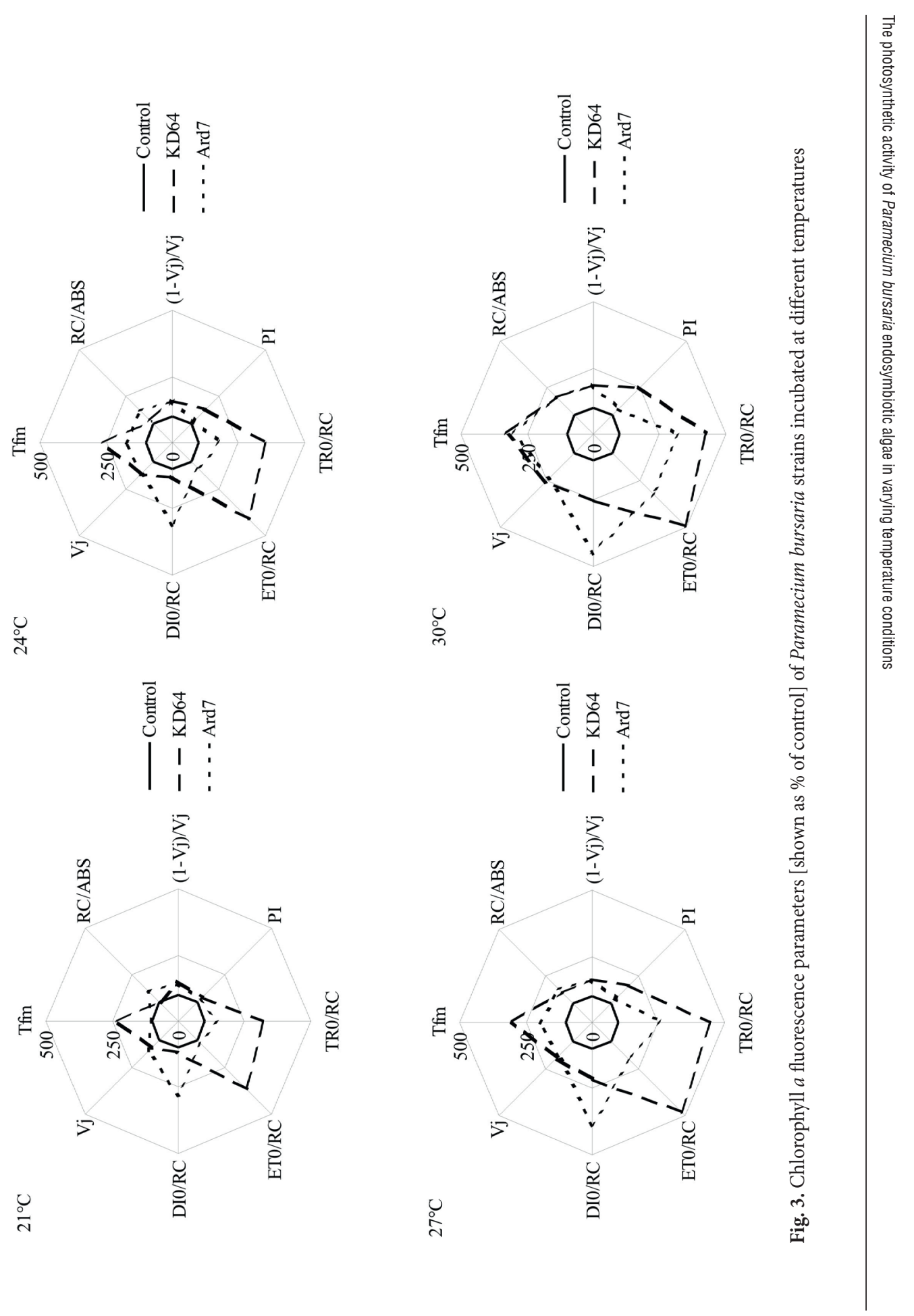

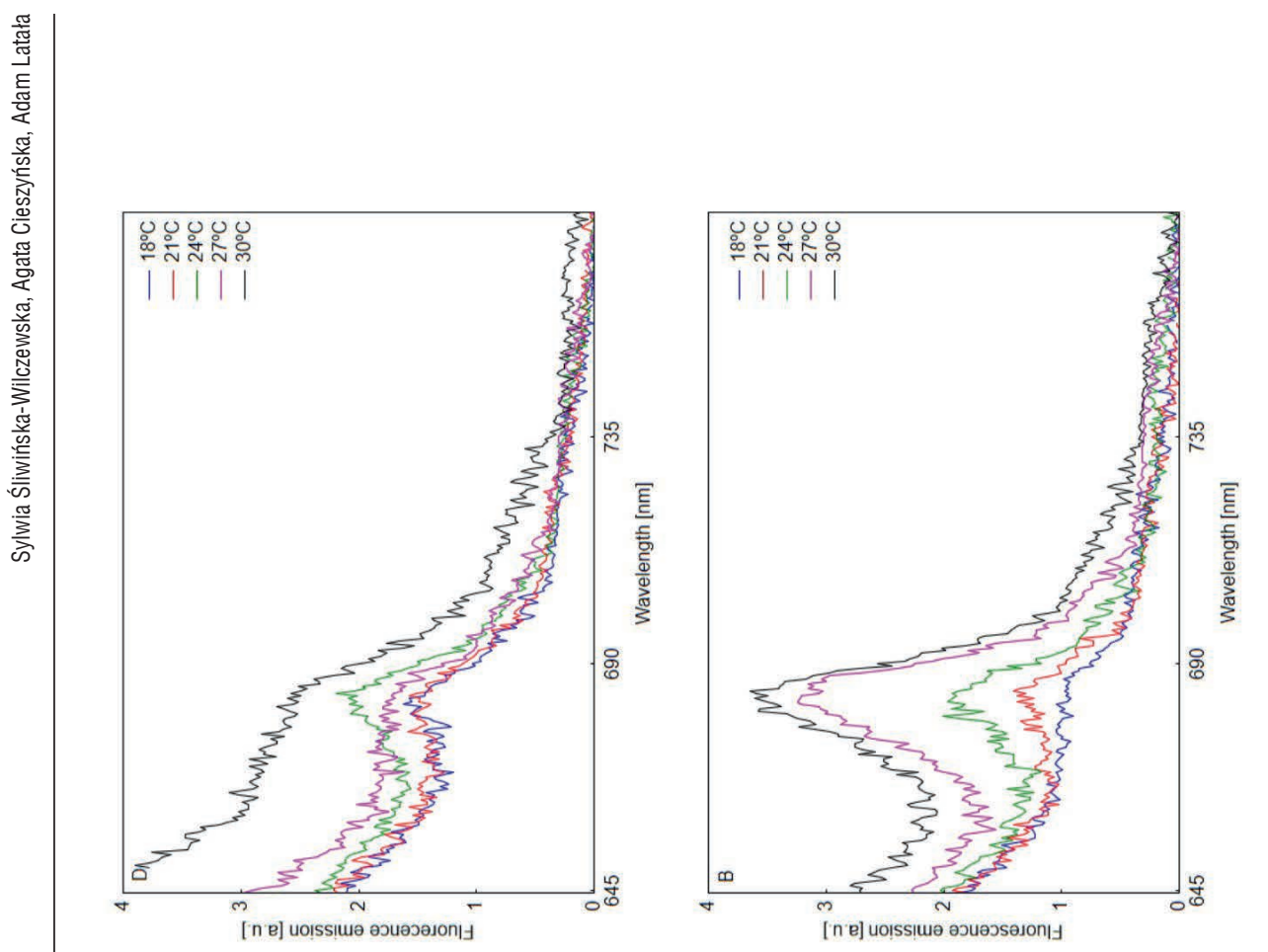

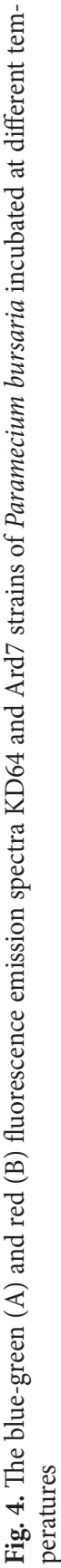


was clearly shown at two wavelengths. The first peak was observed at a wavelength $450-460 \mathrm{~nm}$, and the second peak was at $485-490 \mathrm{~nm}$. The blue-green fluorescence emissions at $21^{\circ} \mathrm{C}$ were similar to the control group. The fluorescence emission increased with temperature.

Red fluorescence emission spectra for both strains of $P$. bursaria were characterised by a distinct peak at a wavelength $675-685 \mathrm{~nm}$ with an arm at $750 \mathrm{~nm}$. Fluorescence intensity increased at temperatures $24^{\circ} \mathrm{C}$ to $30^{\circ} \mathrm{C}$.

The values of F450/F685, F450/F735, F485/F685, and F485/F735 for P. bursaria strains decreased with increasing temperature. The parameter F450/F530 increased with temperature, and the highest value was observed at $30^{\circ} \mathrm{C}$ (Tab. 1).

Tab. 1. Fluorescence emission factors values of Ard7 - (A) and KD64 - (B) strains incubated at different temperatures. Values shown as different letters within the line differ significantly according to the Duncan test at $\mathrm{p} \leq 0.05 ; \mathrm{n}=5$

\begin{tabular}{|c|c|c|c|c|c|c|c|c|c|c|}
\hline \multirow{3}{*}{ Ratio } & \multicolumn{10}{|c|}{ Temperature $\left[{ }^{\circ} \mathrm{C}\right]$} \\
\hline & \multicolumn{2}{|c|}{18} & \multicolumn{2}{|c|}{21} & \multicolumn{2}{|c|}{24} & \multicolumn{2}{|c|}{27} & \multicolumn{2}{|c|}{30} \\
\hline & $\mathrm{A}$ & $\mathrm{B}$ & $\mathrm{A}$ & $\mathrm{B}$ & A & $\mathrm{B}$ & A & $\mathrm{B}$ & A & $\mathrm{B}$ \\
\hline F450/F685 & $65.5^{\mathrm{a}}$ & $49.1^{\mathrm{b}}$ & $48.5^{\mathrm{b}}$ & $45.9^{\mathrm{bc}}$ & $40.9^{\mathrm{bcd}}$ & $42.7^{\mathrm{bcd}}$ & $36.90^{\mathrm{cd}}$ & $44.2^{\mathrm{bcd}}$ & $26.9^{\mathrm{e}}$ & $35.2^{\mathrm{d}}$ \\
\hline F450/F735 & $652.7^{\mathrm{a}}$ & $341.9^{\mathrm{ab}}$ & $392.0^{\mathrm{ab}}$ & $339.5^{\mathrm{ab}}$ & $373.3^{\mathrm{ab}}$ & $299.2^{\mathrm{ab}}$ & $298.5^{\mathrm{ab}}$ & $292.9^{\mathrm{ab}}$ & $278.1^{\mathrm{b}}$ & $262.6^{\mathrm{b}}$ \\
\hline F450/F530 & $1.43^{\mathrm{c}}$ & $1.10^{\mathrm{g}}$ & $1.46^{\mathrm{bc}}$ & $1.27^{\mathrm{f}}$ & $1.47^{\mathrm{b}}$ & $1.27^{\mathrm{f}}$ & $1.47^{\mathrm{b}}$ & $1.30^{\mathrm{e}}$ & $1.72^{\mathrm{a}}$ & $1.40^{\mathrm{d}}$ \\
\hline F485/F685 & $72.3^{\mathrm{a}}$ & $52.9^{\mathrm{bc}}$ & $52.6^{\mathrm{bc}}$ & $56.1^{\mathrm{b}}$ & $44.6^{\mathrm{cd}}$ & $49.3^{\text {bcd }}$ & $44.0^{\mathrm{cd}}$ & $48.3^{\text {bcd }}$ & $29.2^{\mathrm{e}}$ & $40.2^{\mathrm{d}}$ \\
\hline F485/F735 & $724.2^{\mathrm{a}}$ & $394.0^{\mathrm{ab}}$ & $466.3^{\mathrm{ab}}$ & $391.6^{\mathrm{ab}}$ & $407.6^{\mathrm{ab}}$ & $341.1^{\mathrm{ab}}$ & $323.5^{\mathrm{ab}}$ & $320.6^{\mathrm{ab}}$ & $301.0^{\mathrm{b}}$ & $300.2^{\mathrm{b}}$ \\
\hline F685/F735 & $6.1^{\mathrm{a}}$ & $5.4^{\mathrm{a}}$ & $9.2^{\mathrm{a}}$ & $6.6^{\mathrm{a}}$ & $9.8^{\mathrm{a}}$ & $8.0^{\mathrm{a}}$ & $10.5^{\mathrm{a}}$ & $7.4^{\mathrm{a}}$ & $10.6^{\mathrm{a}}$ & $8.5^{\mathrm{a}}$ \\
\hline
\end{tabular}

Discussion

Temperature has a major structuring effect at all levels of biological organisation. At the cell level, the temperature affects both energetic requirements and division rates, growth rate, and the decomposition and exchange of carbon dioxide and oxygen. The functioning of the whole ecosystems depends on temperature (Brown et al., 2004; Savage et al., 2004).

Green algae tolerance is not the same for constant and variable temperature treatments (Feder, Hofmann, 1999). Ciliates respond promptly and differently to environmental change (Jiang, Morin, 2004; Esteban, Finlay, 2007). In the present study, there was revealed a significant effect of temperature on the photosynthetic activity of endosymbionts inside the Paramecium bursaria cells, which originated from a warm and cold climate. One-week incubation of ciliates at different temperatures caused changes in chlorophyll $a$ fluorescence parameters (Fig. 2-3), and an increase of fluorescence 
emission intensity (Fig. 4). The values of emission fluorescence ratios (F450/F530 and F685/F730) were increased with temperature (Tab. 1). These changes may indicate a decrease in the efficiency of primary reactions occurring in PSII and the activation of defence mechanisms of endosymbiont photosynthetic apparatus (Lichtenthaler, Rinderle, 1988; Chemeris et al., 2004). At high temperatures, cell membrane permeability and damage of PSII subunits increase (Kota et al., 2002). The changes are observed (I) in the structure of proteins and lipids, (II) in the functioning of ion channels, (III) disturbances in electron transport and in the reduction of electron acceptors, (IV) in the efficiency of oxygen extraction, and (V) the dissipation of heat (Weng, Lai, 2005). High temperatures cause a blockade of energy transfer from the reaction centre to plastochinone (Reigosa, Weiss, 2001). Changes in F450/F530 values indicate an increase in phenolic compounds, and changes in F685/F730 values indicate a decrease in chlorophyll content (Lang et al., 1991; Lichtenthaler et al., 2004).

The rate of $P$. bursaria metabolism depends on the number of endosymbiotic Chlorella cells and their photosynthetic activity (Weis, 1969). The photosynthetic products of symbiotic green algae increase the tolerance to high temperatures of the host cell (Iwatsuki et al., 1998). P. bursaria cells with Chlorella algae are more tolerant to high temperatures than algae-free ciliates (Miwa, 2009).

The studies on the effect of temperature on the morphology and physiology of algae show that the optimal growth temperatures for Chlorella vulgaris range from $26^{\circ} \mathrm{C}$ to $34^{\circ} \mathrm{C}$ (Mayo, 1997; Ma et al., 2014). Duncan et al. (2011) showed that Paramecium from variable environments grow well at both $23^{\circ} \mathrm{C}$ and $35^{\circ} \mathrm{C}$. At temperatures from $29^{\circ} \mathrm{C}$ to $39^{\circ} \mathrm{C}$, Chlorella sp. strain R-06/2 originating from geothermal source in Rupite (Bulgaria) is highly photosynthetically efficient (Gacheva, Pilarski, 2008). Under natural lighting conditions, the highest increase in chlorophyll content, carotenoids and proteins in C. vulgaris are observed at temperatures from $25^{\circ} \mathrm{C}$ to $30^{\circ} \mathrm{C}$. Under continuous light conditions and at temperatures from $30^{\circ} \mathrm{C}$ to $35^{\circ} \mathrm{C}$, algae growth is minimal (Sharma et al., 2012). Changes in physiological properties are due to the endosymbiotic close relationship between paramecium and algae (Reisser, 1986). According to McAuley et al. (1996), the host regulates the growth of symbiotic algae. In the present study, the higher differences in photosynthetic activity were observed in the KD64 strain from Kamchatka (Fig. 2-4; Tab. 1).

The environmental stressors may cause many adverse changes in aquatic ecosystems, as well as for the economy and human health. That is why it attaches great importance to ensuring continuous monitoring of waters, so that changes can be noted and appropriate corrective or preventive measures taken in the natural environment. Given the significant ecological role played by ciliates, it is important to understand how temperature affects the adaptation of organisms in their local environment. 
The study showed a significant effect of temperature on the activity of the photosynthetic apparatus of the Paramecium bursaria green endosymbionts. With an increase of temperature, changes in PSII were observed. High temperature caused an increase of blue-green and red fluorescence emission of endosymbiotic algae. The strain of P. bursaria from Kamchatka (KD64) was more sensitive than the strain from Admore (Ard7).

\section{References}

Albers, D., Wiessner, W. (1985). Nitrogen nutrition of endosymbiotic Chlorella spec. Endocytobiosis Cell Research, 1, 55-64.

Brown, J.A., Nielsen, P.J. (1974). Transfer of photosynthetically produced carbohydrate from endosymbiotic Chlorellae to Paramecium bursaria. The Journal of Protozoology, 21, 569-570.

Brown, J.H., Gillooly, J.F., Allen, A.P., Savage, V.M., West, G.B. (2004). Toward a metabolic theory of ecology. Ecology, 85, 1771-89. DOI: 10.1890/03-9000

Chemeris, Y.K., Korol'kov, N.S., Seifullina, N.K., Rubin, A.B. (2004). Changes in the contents of inactive complexes of photosystem II in Chlorella cells incubated in the light and darkness. Russian Journal of Plant Physiology, 51, 287-293. DOI: 10.1023/B:RUPP.0000028673.79956.a2

Duncan, A.B., Fellous, S., Quillery, E., Kaltz, O. (2011). Adaptation of Paramecium caudatum to variable conditions of temperature stress. Research in Microbiology, 162, 939-944. DOI: 10.1016/j.resmic.2011.04.012

Esteban, G.F., Finlay, B.J. (2007). Exceptional species richness of ciliated Protozoa in pristine intertidal rock pools. Marine Ecology Progress Series, 335, 133-141. DOI: 10.3354/meps3351338

Feder, M.E., Hofmann, G.E. (1999). Heat-shock proteins, molecular chaperones, and the stress response: evolutionary and ecological physiology. Annual Review of Physiology, 61, 243-282. DOI: 10.1146/ annurev.physiol.61.1.243

Gacheva, G., Pilarski, P. (2008). The resistance of a new strain Chlorella sp. R-06/2, isolated from an extreme habitat to environmental stress factors. General and Applied Plant Physiology, 34(3-4), 347-360.

Iwatsuki, K., Nishidoi, M., Suehiro, K. (1998). Symbiotic Chlorella enhances the thermal tolerance in Paramecium bursaria. Comparative Biochemistry and Physiology - Part A: Molecular \& Integrative Physiology, 121, 405-409. DOI: 10.1016/S1095-6433(98)10151-4

Jessup, C.M., Kassen, R., Forde, S.E., Kerr, B., Buckling, A., Rainey., P.B., Bohannan, B.J. (2004). Big questions, small worlds: microbial model systems in ecology. Trends in Ecology \& Evolution, 19, 189-197. DOI: 10.1016/j.tree.2004.01.008

Jiang, L., Morin, P.J. (2004). Temperature-dependent interactions explain unexpected responses to environmental warming in communities of competitors. Journal of Animal Ecology, 73, 569-576. DOI: 10.1111/j.0021-8790.2004.00830.x

Karakashian, S.J., Karakashian, M.W., Rudzińska, M.A. (1968). Electron microscopic observations on the symbiosis of Paramecium bursaria and its intracellular algae. Journal of Eukaryotic Microbiology, 15, 113-118. DOI: 10.1111/j.1550-7408.1968.tb02095.x

Kodama, Y., Fujishima, M. (2005). Symbiotic Chlorella sp. of the ciliate Paramecium bursaria do not prevent acidification and lysosomal fusion of host digestive vacuoles during infection. Protoplasma, 225, 191-203. DOI: 10.1007/s00709-005-0087-5 
Kota, Z., Horvath, L.I., Droppa, M., Horvath G., Farkas, T., Pali, T. (2002). Protein assembly and heat stability in developing thylakoid membranes during greening. Proceedings of the National Academy of Sciences, 99, 12149-12154. DOI: 10.1073/pnas.192463899

Lang, M., Stober, F., Lichtenthaler, H.K. (1991). Fluorescence emission spectra of plant leaves and plant constituents. Radiation and Environmental Biophysics, 30, 333-347. DOI: 10.1007/BF01210517

Lichtenthaler, H.K., Knapp, M., Buschmann, C. (2004). Recording chlorophyll fluorescence emission spectra with the Perkin Elmer fluorescence spectrometer LS 50. In: M. Filek, J. Biesaga-Kościelniak, I. Marcińska (eds.), Analytical methods in plant stress biology. Kraków: Drukrol, 112-124.

Lichtenthaler, H.K., Rinderle, U. (1988). The role of chlorophyll fluorescence in the detection of stress conditions in plants. Critical Reviews in Analytical Chemistry, 19, S29-S85.

Ma, X., Zheng, H., Huang, H., Liu, Y., Ruan, R. (2014). Effects of temperature and substrate concentration on lipid production by Chlorella vulgaris from enzymatic hydrolysates of lipid-extracted microalgal biomass residues (LMBRs). Applied Biochemistry and Biotechnology, 174(4), 1631-1650. DOI: 10.1007/s12010-014-1134-5

Mayo, A.W. (1997). Effects of temperature and $\mathrm{pH}$ on the kinetic growth of unialga Chlorella vulgaris cultures containing bacteria. Water Environment Research, 69(1), 64-72. DOI: 10.2175/106143097X125191

McAuley, J.P., Dorling, M., Hodge, H. (1996). Effect of maltose release on uptake and assimilation of ammonium by symbiotic Chlorella (Chlorophyta). Journal of Phycology, 32, 839-846. DOI: 10.1111/j.0022-3646.1996.00839.x

Miwa, I. (2009). Regulation of circadian rhythms of Paramecium bursaria by symbiotic Chlorella species. In: M. Fujishima (ed.) Endosymbionts in Paramecium. Microbiology Monographs, 12, 83-110.

Morgan-Kiss, R., Ivanov, A.G., Williams, J., Khan, M., Huner, N.P.A. (2002). Differential thermal effects on the energy distribution between photosystem II and photosystem I in thylakoid membranes of a psychrophilic and a mesophilic alga. Biochimica et Biophysica Acta (BBA)-Biomembranes, 1561(2), 251-265. DOI: 10.1016/S0005-2736(02)00352-8

Reigosa, R.M.J., Weiss, O. (2001). Fluorescence techniiques. In: R.M. Reigosa (ed.) Handbook of plant ecophysiology techniques. Dordrecht: The Netherlands Kluwer Academic Publishers, 155-171.

Reisser, W. (1980). The metabolic interactions between Paramecium bursaria and Chlorella spec. in the Paramecium bursaria-symbiosis. Archives of Microbiology, 125, 291-293. DOI: 10.1007/BF00446890

Reisser, W. (1986). Endosymbiotic associations of freshwater protozoa and algae. Program Protistolgy, 1, 195-214.

Savage, V.M., Gillooly, J.F., Brown, J.H., West, G.B., Charnov, E.L. (2004). Effects of body size and temperature on population growth. American Naturalist, 163, 429-441. DOI: 10.1086/381872

Sharma, R., Singh, G.P., Sharma, V.K. (2012). Effects of culture conditions on growth and biochemical profile of Chlorella vulgaris. Journal of Plant Pathology and Microbiology, 3(5), 1-6. DOI: 10.4172/21577471.1000131

Sommaruga, R., Sonntag, B. (2009). Photobiological aspects of the mutualistic association between Paramecium bursaria and Chlorella. In: M. Fujishima (ed.), Endosymbionts in Paramecium. Microbiology Monographs, 12, 111-130. DOI: 10.1007/978-3-540-92677-1_5

Sonneborn, T.M. (1970). Methods in Paramecium research. In: E.D.M Prescott (ed.), Methods in cell biology. New York: Academy Press, 241-339.

Strasser, R.J., Strvastava, A., Govindjee (1995). Polyphasic chlorophyll a fluorescence transient in plants and cyanobacteria. Photochemistry and Photobiology, 61, 32-34. DOI: 10.1111/j.1751-1097.1995. tb09240.x

Weis, D.S. (1969). Regulation of host and symbiont population size in Paramecium bursaria. Experientia, 25(6), 664-6. 
Weng, J.H., Lai, M.F. (2005). Estimating heat tolerance among plant species by two chlorophyll fluorescence parameters. Photosynthetica, 43, 439-444. DOI: 10.1007/s11099-005-0070-6

Wilson, K.E., Huner, N.P. (2000).The role of growth rate, redox-state of the plastoquinone pool and the trans-thylakoid deltapH in photoacclimation of Chlorella vulgaris to growth irradiance and temperature. Planta, 212(1), 93-102. DOI: 10.1007/s004250000368

\section{Abstract}

The aim of this study was to investigate the effect of higher temperatures on the photosynthesis of endosymbiotic Chlorella sp. of two Paramecium bursaria Ehrenberg 1831 strains originating from regions with a warmer and colder climate (Ardmore - USA and Kamchatka - Russia, respectively). After seven days of protozoa incubation at $18^{\circ} \mathrm{C}$ (control), $21^{\circ} \mathrm{C}, 24^{\circ} \mathrm{C}, 27^{\circ} \mathrm{C}, 30^{\circ} \mathrm{C}$ and $33^{\circ} \mathrm{C}$, the chlorophyll $a$ fluorescence measurements were carried out and fluorescence spectra were measured in blue-green and red light. As a result of the studies, a significant effect of higher temperature on the photosynthesis process of $P$. bursaria endosymbionts was observed. Weekly incubation at $33^{\circ} \mathrm{C}$ was lethal for both protozoan strains in comparison to the control temperature $\left(18^{\circ} \mathrm{C}\right)$. The blue-green fluorescence spectra were characterised by marked peaks at $450 \mathrm{~nm}$ and $490 \mathrm{~nm}$. Within the red light range, the peak was observed at about $690 \mathrm{~nm}$ with a lesser arm at $730 \mathrm{~nm}$. Endosymbionts from Kamchatka were more sensitive to the temperature increase than algae from areas with relatively warm climates.

Key words: emission fluorescence, high temperatures, PSII activity, spectrofluorimetry, Chlorella vulgaris

Received: [2017.08.13]

Accepted: [2017.11.14]

\section{Aktywność fotosyntetyczna endosymbiotycznych glonów Paramecium bursaria w zróżnicowanych warunkach temperatury \\ Streszczenie}

Celem niniejszej pracy było zbadanie wpływu podwyższonej temperatury na przebieg procesu fotosyntezy endosymbiontów z gatunku Chlorella sp. dwóch szczepów Paramecium bursaria Ehrenberg 1831, pochodzących z terenów o niskich i wysokich temperaturach powietrza (Ardmore - USA i Kamczatka - Rosja). Po 7 dniach inkubacji pierwotniaków w każdej z temperatur $18^{\circ} \mathrm{C}$ (kontola), $21^{\circ} \mathrm{C}, 24^{\circ} \mathrm{C}, 27^{\circ} \mathrm{C}, 30^{\circ} \mathrm{C}$ i $33^{\circ} \mathrm{C}$ przeprowadzono pomiary fluorescencji chlorofilu $a$ i wyznaczono widma emisji fluorescencji w zakresie niebiesko-zielonym i czerwonym. W wyniku przeprowadzonych badań zaobserwowano istotny wpływ podwyższonej temperatury na proces fotosyntezy endosymbiontów $P$. bursaria. Tygodniowa inkubacja w temperaturze $33^{\circ} \mathrm{C}$ była letalna dla obu szczepów pierwotniaka, w porównaniu z temperaturą kontrolną $\left(18^{\circ} \mathrm{C}\right)$. Widma emisji fluorescencji niebiesko-zielonej charakteryzowały wyraźnymi pikami przy $450 \mathrm{~nm}$ i $490 \mathrm{~nm}$. W zakresie czerwonym pik zaobserwowano przy około $690 \mathrm{~nm}$ z mało wyraźnym ramieniem przy 730 $\mathrm{nm}$. Endosymbionty szczepu pochodzącego z Kamczatki były bardziej wrażliwe na wzrost temperatury od glonów pochodzących z terenów o stosunkowo ciepłym klimacie.

Słowa kluczowe: wysoka temperatura, aktywność PSII, spektrofluorymetria, szczepy Chlorella vulgaris

\section{Information on the authors}

\section{Katarzyna Możdżeń}

Her scientific interests concentrate on the effects of different environmental factors (light, ozone, heavy metals, allelopathic extracts) on the morphology and physiology plants cultivated, protected, and invasive species.

\section{Patrycja Zagata Leśnicka}

She is graduate of Doctoral Studies at the Institute of Biology at the Pedagogical University in Kraków. Her scientific interests concern microbiology and algology, and especially the endosymbionts of Paramecium bursaria. 


\section{Mateusz Ślęczka}

He graduated from the Environmental Protection at the Pedagogical University in Kraków. His scientific interests concern environmental microbiology.

\section{Magdalena Greczek-Stachura}

She is associate professor at the Pedagogical University in Cracow. Her interest is in the broadly understood microbiology and algology. In recent years, her research has focused on endosymbiosis in a group of Ciliata (animal Protista). 